\title{
Article \\ Expression and Functional Characterization of $c$-Fos Gene in Chinese Fire-Bellied Newt Cynops orientalis
}

\author{
Gang Ye ${ }^{1}$, Yalong Feng ${ }^{1}$, Zhaoxiang Mi ${ }^{1}$, Du Wang ${ }^{1}$, Shuai Lin ${ }^{1}$, Fulin Chen ${ }^{1,2,3}$, Jihong Cui ${ }^{1,2,3}$ and \\ Yuan Yu 1,2,3,* \\ 1 Lab of Tissue Engineering, College of Life Sciences, Northwest University, Xi'an 710069, China; \\ yegnwu@163.com (G.Y.); fengylnwu@163.com (Y.F.); mizxnwu@163.com (Z.M.); wangdnwu@163.com (D.W.); \\ linshnwu@163.com (S.L.); chenfl@nwu.edu.cn (F.C.); cjh@nwu.edu.cn (J.C.) \\ 2 Provincial Key Laboratory of Biotechnology of Shaanxi, Northwest University, Xi'an 710069, China \\ 3 Key Laboratory of Resource Biology and Biotechnology in Western China, Ministry of Education, \\ School of Medicine, Northwest University, Xi'an 710069, China \\ * Correspondence: yuyuan@nwu.edu.cn
}

Citation: Ye, G.; Feng, Y.; Mi, Z.; Wang, D.; Lin, S.; Chen, F.; Cui, J.; Yu, Y. Expression and Functional Characterization of $c$-Fos Gene in Chinese Fire-Bellied Newt Cynops Orientalis. Genes 2021, 12, 205.

https: / / doi.org/10.3390/

genes12020205

Academic Editor:

Erich Bornberg-Bauer

Received: 6 January 2021

Accepted: 28 January 2021

Published: 30 January 2021

Publisher's Note: MDPI stays neutral with regard to jurisdictional claims in published maps and institutional affiliations.

Copyright: (C) 2021 by the authors. Licensee MDPI, Basel, Switzerland. This article is an open access article distributed under the terms and conditions of the Creative Commons Attribution (CC BY) license (https:/ / creativecommons.org/licenses/by/ $4.0 /)$.

\begin{abstract}
Fos is an immediate-early gene that modulates cellular responses to a wide variety of stimuli and also plays an important role in tissue regeneration. However, the sequence and functions of $c$-Fos are still poorly understood in newts. This study describes the molecular cloning and characterization of the $c$-Fos gene ( $\mathrm{Co}-\mathrm{c}-\mathrm{Fos})$ of the Chinese fire-bellied newt, Cynops orientalis. The full-length Co-c-Fos cDNA sequence consists of a 1290 bp coding sequence that encoded 429 amino acids. The alignment and phylogenetic analyses reveal that the amino acid sequence of Co-c-Fos shared a conserved basic leucine zipper domain, including a nuclear localization sequence and a leucine heptad repeat. The Co-c-Fos mRNA is widely expressed in various tissues and is highly and uniformly expressed along the newt limb. After limb amputation, the expression of Co-c-Fos mRNA was immediately upregulated, but rapidly declined. However, the significant upregulation of Co-c-Fos protein expression was sustained for $24 \mathrm{~h}$, overlapping with the wound healing stage of $C$. orientalis limb regeneration. To investigate if $\mathrm{Co}-\mathrm{C}$-Fos participate in newt wound healing, a skin wound healing model is employed. The results show that the treatment of T-5224, a selective c-Fos inhibitor, could largely impair the healing process of newt's skin wound, as well as the injury-induced matrix metalloproteinase-3 upregulation, which is fundamental to wound epithelium formation. These data suggest that $\mathrm{Co}-\mathrm{c}$-Fos might participate in wound healing by modulating the expression of its potential target gene matrix metalloproteinase-3. Our study provides important insights into mechanisms that are responsible for the initiation of newt limb regeneration.
\end{abstract}

Keywords: Cynops orientalis; c-Fos; expression patterns; limb regeneration; skin wound healing

\section{Introduction}

The ability to regenerate lost or damaged tissue will be of great benefit to those who suffer from organ failure or severe trauma. However, adult mammals have very limited capacities for tissue regeneration. Urodele amphibians, such as axolotls and newts, possess the remarkable ability to regenerate lost or damaged body parts, including the ocular tissues, tail, nervous system, and limbs throughout their entire lives [1]. Among the tissues and organs that can regenerate, the limb has been most extensively studied, making it an accepted model for revealing the mechanisms regulating tissue and organ regeneration $[2,3]$. Successful limb regeneration begins with wound healing, followed by limb bud formation and a final redevelopment phase [2]. Prior studies have noted the importance of matrix metalloproteinases (MMPs) in salamander limb regeneration [4-6]. Among these MMP genes, MMP-3 (also known as stromelysin-1) is upregulated in migrating epithelial cells within hours of limb amputation and facilitates healing of the wound, which 
is fundamental to the following regenerative processes [6,7]. However, the mechanisms that are responsible for the early induction of $M M P-3$ expression remain ambiguous.

Immediate-early genes (IEGs) comprise a group of genes that are rapidly and transiently activated following a variety of extracellular signals, such as growth factors, developmental signals, stress, and cell injury [8]. In recent years, researchers have focused on IEGs for their critical roles in cellular functions, including proliferation, differentiation, and metabolism [9]. Among other IEGs, c-Fos was originally isolated from mouse genomic DNA as a cellular counterpart of the $v$-Fos carried by the Finkel-Biskis-Jinkins osteosarcoma virus. Then, it was identified in humans [10], rats [11], chickens [12], and fish [13] in succession. C-Fos is expressed in various cell types and dimerizes with c-Jun to form the transcription factor, activator protein 1 (AP-1), which binds to the target gene DNA to regulate various cellular functions, including cell cycle progression [14], cell dedifferentiation [15], and extracellular matrix re-organization [16]. In mammalians, c-Fos plays an important role in skin wound healing [17], and regenerative processes of the central nervous system [18], bone [19], and liver [20]. Recently, it has been reported that the upregulation of $c$-Fos expression is critical to initiating a pro-regenerative response after spinal cord injury in the axolotl [21]. These pieces of evidence inspire us to investigate whether $c$-Fos plays a part in newt limb regeneration.

In this study, a full-length c-Fos cDNA was cloned from Cynops orientalis, the Chinese fire-bellied newts exhibiting an extraordinary capacity to regenerate their limbs after amputation [22-24], and the amino acid sequence of C. orientalis c-Fos (Co-c-Fos) gene was determined. Then the multiple sequence alignment and phylogenetic analysis were performed. Finally, we investigated the expression pattern of the newt c-Fos gene and its potential role in the process of newt limb regeneration.

\section{Materials and Methods}

\subsection{Animals and Sample Collection}

C. orientalis has a remarkable capacity of regenerating an entire limb post-amputation and is widely distributed in China. Adult newts used in this study were obtained from Dabie Mountain (Huanggang, China). Animals of 8-10 cm nose-to-tail length were maintained in individual aquaria at $22 \pm 2{ }^{\circ} \mathrm{C}$. All surgeries were performed under anesthesia with $0.1 \%$ Tricaine methanesulfonate (MS-222, Sigma-Aldrich, St. Louis, MI, USA), and all efforts were made to minimize suffering. The tissue samples, including the spleen, heart, intestine, dorsal root ganglia, limb, tail, liver, kidney, and stomach, were collected for RNA isolation immediately after the animals were sacrificed.

The newt limb regeneration experiment was performed as previously described [22,23]. Briefly, the newt limbs were amputated at the right upper arm, and then the protruding bones were trimmed. The regenerated limb samples were collected at $15 \mathrm{~min}, 30 \mathrm{~min}$, $45 \mathrm{~min}, 1 \mathrm{~h}, 3 \mathrm{~h}, 6 \mathrm{~h}, 12 \mathrm{~h}, 1 \mathrm{~d}, 3 \mathrm{~d}, 7 \mathrm{~d}, 14 \mathrm{~d}, 30 \mathrm{~d}, 42 \mathrm{~d}$ post-amputation by cutting the arm $2 \mathrm{~mm}$ from the first amputation plane. At the same position, the limb tissue before amputation was used as control.

To establish a skin wound healing model, a circular piece of skin ( $1.5 \mathrm{~mm}$ in diameter) was carefully removed from the right upper arms, making sure not to damage the underlying muscle. Then, the samples were collected at $15 \mathrm{~min}, 30 \mathrm{~min}, 45 \mathrm{~min}, 1 \mathrm{~h}, 3 \mathrm{~h}, 6 \mathrm{~h}, 12 \mathrm{~h}$, $1 \mathrm{~d}$, and $3 \mathrm{~d}$ after wounding for RNA isolation. The limb tissue before wounding was used as the control. To visualize the wound closure, Fast Green (Sigma, USA) was used to stain damaged tissues and dead cells in the wound area [25].

\subsection{PCR Amplification and Quantitative Real-Time PCR ( $q R T-P C R$ ) Analysis}

Total RNA was extracted from each sample using RNAiso Plus reagent (Takara, Beijing, China), and the reverse transcription was performed to generate cDNA using a Transcriptor First Strand cDNA Synthesis Kit (Roche, Basel, Switzerland). To obtain the complete coding sequence of $\mathrm{Co}-\mathrm{c}-\mathrm{Fos}$ gene, $\mathrm{PCR}$ amplification was performed with the following procedure: $5 \mathrm{~min}$ at $95^{\circ} \mathrm{C} ; 30 \mathrm{~s}$ at $95^{\circ} \mathrm{C}, 45 \mathrm{~s}$ at $52{ }^{\circ} \mathrm{C}, 90 \mathrm{~s}$ at $72{ }^{\circ} \mathrm{C}$ for 35 cycles; 
8 min at $72{ }^{\circ} \mathrm{C}$. The qRT-PCR analysis was performed using SYBR Premix Ex Taq (TaKaRa, China) and a CFX96 ${ }^{\mathrm{TM}}$ Real-Time PCR Detection System (Bio-Rad, Hercules, CA, USA) with the following parameters: $95^{\circ} \mathrm{C}$ for $10 \mathrm{~s}$; followed by 40 cycles at $95^{\circ} \mathrm{C}$ for $5 \mathrm{~s}$; and $60{ }^{\circ} \mathrm{C}$ for $30 \mathrm{~s}$. $\beta$-actin housekeeping gene was selected as an internal reference for the analysis. For each cDNA sample, the target and reference genes were amplified independently in the same experimental run in triplicate. The relative gene expression level (amount of target normalized to the internal reference) was calculated using the $2^{-\Delta \Delta C t}$ method. PCR primers used in this study were designed based on transcriptome sequencing, as shown in Table S1.

\subsection{Bioinformatic Analyses}

DNAMAN software (7.0) was used to analyze the obtained cDNA and deduced amino acid sequence of $\mathrm{Co}-\mathrm{c}$-Fos. The conserved domains of $\mathrm{Co}-\mathrm{c}$-Fos were predicted using the Conserved Domain Database tool in NCBI (https:/ / www.ncbi.nlm.nih.gov/Structure/cdd/ wrpsb.cgi) and the 2ZIP program [26] (http://2zip.molgen.mpg.de/). The predicted tertiary structure model of the basic leucine zipper (bZIP) domain of Co-c-Fos was constructed with the SWISS-MODEL workspace (https:/ / www.expasy.org/resources/swiss-model). The ProtParam (http:/ / www.expasy.org/tools/protparam.html) were used to calculate the molecular weight and isoelectric point ( $\mathrm{pI}$ ) of Co-c-Fos. Multiple sequence alignment was performed using CLUSTALW (https:/ / www.genome.jp/tools-bin/clustalw) among species, and a consensus sequence was generated using criteria from MultAlin [27]: Uppercase is identity; lowercase is consensus level $>0.5 ;$ ! is anyone of IV; $\$$ is anyone of LM; \% is anyone of FY; \# is anyone of NDQEBZ. Nuclear localization sequence (NLS) was predicated by using the NLSdb database (https:/ / rostlab.org/services/nlsdb/). Through the neighbor-joining $(\mathrm{NJ})$ method, a phylogenetic tree was constructed by MEGA 5.05.

\subsection{Sectioning and Histological Staining}

Samples were fixed with $4 \%$ paraformaldehyde for $24 \mathrm{~h}$ at $4{ }^{\circ} \mathrm{C}$ and then decalcified by $10 \%$ EDTA for 14 days. Samples were embedded in paraplast and sectioned at $4 \mu \mathrm{m}$. The slides were stained with Masson's Trichrome using standard procedures.

\subsection{Western Blot}

Total protein and nuclear protein were isolated from the newt limbs $(n=6$ per biological replicate) by using RIPA lysis buffer (Beyotime, Shanghai, China) and the Nuclear and Cytoplasmic Protein Extraction Kit (Beyotime, Shanghai, China), respectively. BCA protein assay (Thermo Fisher Scientific, Waltham, MA, USA) was used to quantify the protein contents. Proteins separated by SDS-PAGE were transferred onto PVDF membranes (Millipore, Burlington, MA, USA). The membranes were blocked with 5\% non-fat milk and then incubated with primary antibodies against c-Fos (1:1000, Sangon, Shanghai, China), $\beta$-actin (1:1000, Abmart, Shanghai, China), or histone H3 (1:1000, Cell Signaling Technology, Danvers, MA, USA) at $4{ }^{\circ} \mathrm{C}$ overnight, followed by horseradish peroxidase (HRP)-conjugated goat anti-rabbit IgG (1:5000, Abmart, China) or goat anti-mouse IgG (1:5000, Abmart, China) at room temperature for $1 \mathrm{~h}$. Finally, the membranes were incubated with enhanced chemiluminescence (ECL) reagent (Beyotime, Shanghai, China), and the grayscale values of the bands were analyzed by using ImageJ software.

\subsection{Statistical Analyses}

The data were expressed as means \pm standard error (SE). The statistical differences were calculated using the Student's $t$-test and one-way analysis of variance (ANOVA) in SPSS 17.0 software. Value at $p<0.05$ was considered to be statistically significant. 


\section{Results \\ 3.1. Co-c-Fos cDNA Cloning and Sequence Analyses}

The full-length cDNA sequence of Co-c-Fos was obtained and uploaded to NCBI, and the GenBank number is MG604921.1. The Co-c-Fos cDNA was $1602 \mathrm{bp}$ and composed of an ORF of $1290 \mathrm{bp}$, a $185 \mathrm{bp} 5^{\prime}$-untranslated region (UTR), and a $127 \mathrm{bp} \mathrm{3}$ '-UTR. The predicted Co-c-Fos was a 429 amino acid protein with a bZIP domain, which shared a similar structure with that of the proto-oncogene protein $c$-Fos (SMTL ID: 2wt7.1.A, Figure 1A), and its predicted tertiary structure exhibited continuous $\alpha$-helices (Figure 1B). The molecular weight of the predicted Co-c-Fos was estimated to be $45.86 \mathrm{kDa}$, and the pI was estimated at 4.67 .

A

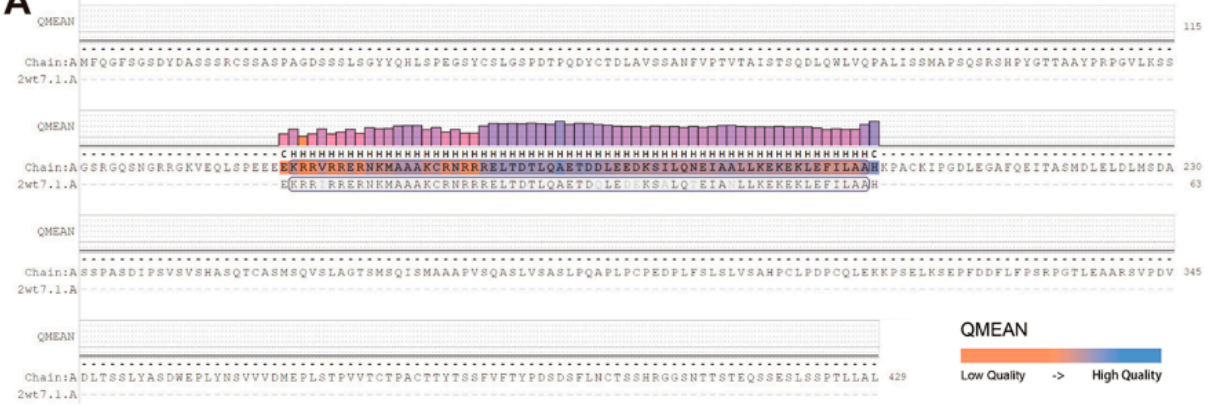

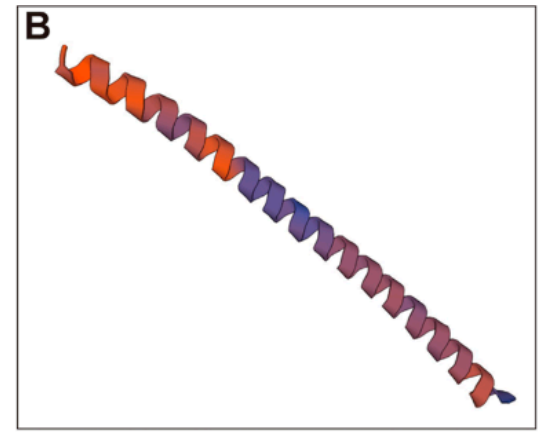

C

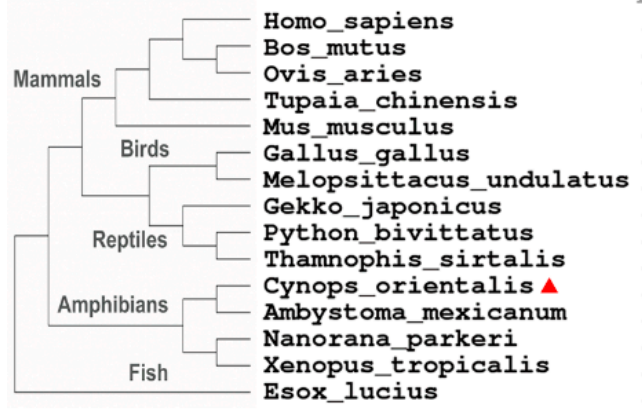

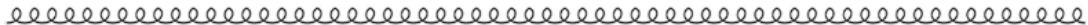

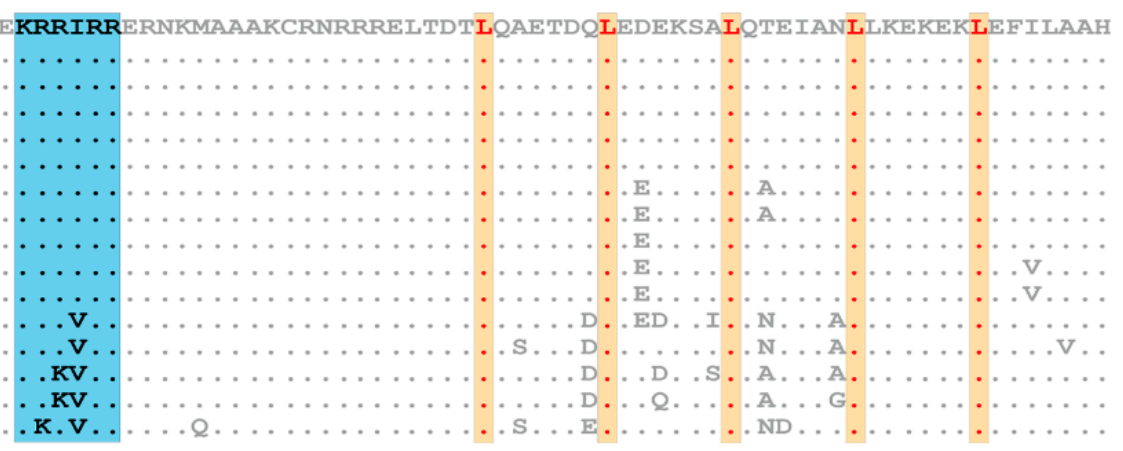

Leucine heptad repeat

Figure 1. Protein structure homology modeling and phylogenetic reconstruction of Co-c-Fos. (A) Target-template alignment. The QMEAN Z-score indicates model quality and is visualized by using bar plots and a color scheme. (B) The predicted secondary structure exhibits continuous $\alpha$-helices, which are displayed in a three-dimensional view. (C) Multiple sequence alignment and phylogenetic analysis of the bZIP domain among vertebrates. The reference sequence corresponds to the human bZIP domain. The predicted NLS (nuclear localization sequence) is shaped in blue, and the heptad-repeat leucines are highlighted in yellow.

To assess the homology of c-Fos proteins among vertebrates, the multiple sequence alignment was performed. The result showed that the amino acid sequence of c-Fos was quite conserved among the selected species (Figure S1). However, Co-c-Fos exhibited higher similarity in amphibians (axolotl and frogs) than in other species, including reptiles, birds, mammals, and fish (Table S2). It was found that the Co-c-Fos protein shared a conserved bZIP domain, with a nuclear localization sequence (NLS) and a leucine heptad repeat included (Figure 1C). Interestingly, the predicted NLS of Co-c-Fos was KRRVRR, and the fourth valine residue was quite conserved among the lower vertebrates, including fish and amphibians, whereas it was KRRIRR for the higher vertebrates. A phylogenetic tree, rooted into Esox lucius, was used to investigate the evolutionary relationships of Co-c-Fos. As shown in Figure 1C, all c-Fos sequences were clustered into two clades. In one clade, the c-Fos sequences from mammals, birds, and reptiles were grouped, and the sequences from amphibians were clustered into the other clade, among which $C$. orientalis was clustered 
with the Mexican axolotl (Ambystoma maculatum). Our results indicated that the branch of $c$-Fos is classified according to the evolutionary positions of the species of fish, amphibians, reptiles, birds, and mammals, and the phylogenetic position of Co-c-Fos is consistent with the location of C. orientalis.

\subsection{Distribution of Co-c-Fos mRNA Expression in Various Tissues of C. orientalis}

qRT-PCR results showed that the mRNA expression levels of Co-c-Fos varied vastly in different tissues (Figure 2A). The Co-c-Fos mRNA was strongly expressed in dorsal root ganglia and kidney; moderately in limb, heart, intestine; and extremely low in the other tissues. To investigate whether the positional pattern of Co-c-Fos gene expression exists along the newt limb, we tested the mRNA expression levels in different segments of a whole limb. As shown in Figure 2B, there was no significant difference in the expression levels of Co-c-Fos among the segments S1, S2, and S3, however, the expression level in the segment $\mathrm{S} 4$ was remarkably lower.
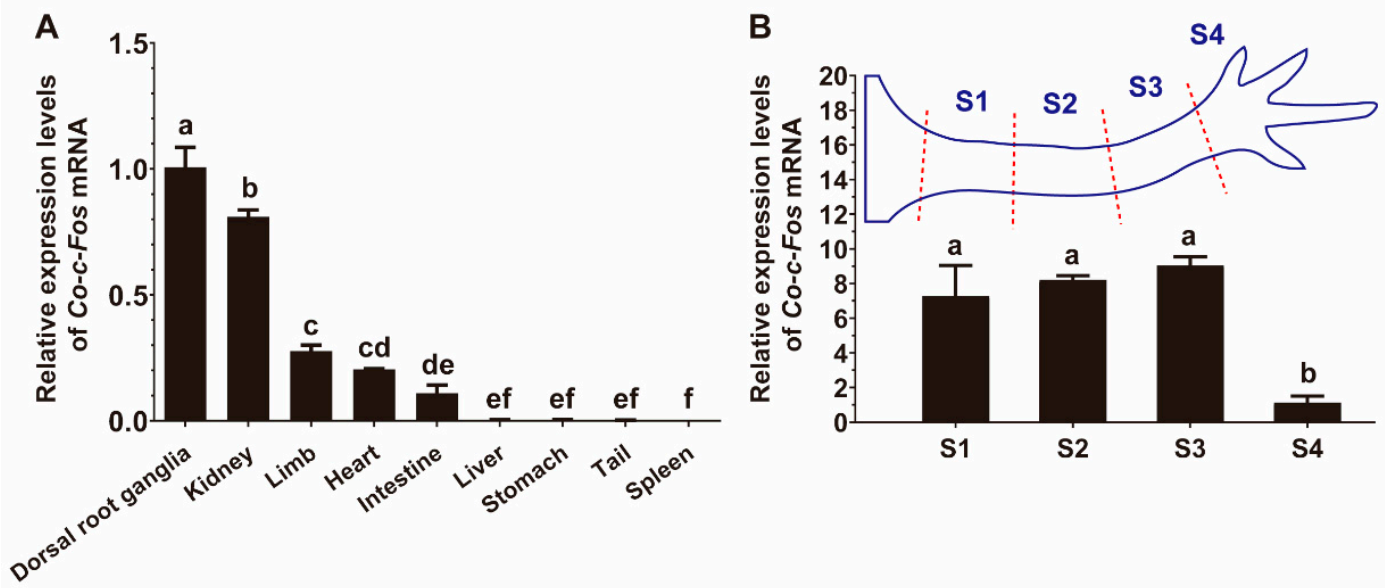

Figure 2. Tissue distribution of Co-c-Fos mRNA expression. (A) Relative mRNA expression levels of Co-c-Fos in various tissues of Cynops orientalis. The mRNA expression level of Co-c-Fos in dorsal root ganglia was set to one $(n=3)$. (B) Relative mRNA expression levels of Co-c-Fos in the four limb segments as illustrated in a cartoon. The mRNA expression level of Co-c-Fos in the S4 segment was set to one $(n=3)$. Data were analyzed using one-way ANOVA with Tukey test, and means with different letters indicated significant statistical difference $(p<0.05)$.

\subsection{Expression Pattern of Co-c-Fos Gene during the Newt Limb Regeneration}

To better understand the expression pattern of the Co-c-Fos gene during C. orientalis limb regeneration, we collected and analyzed the regenerated limb samples at different time points post-amputation. These time points cover major morphological and physiological changes of limb regeneration throughout wound healing (within three days post-amputation, dpa), limb bud formation ( $7 \mathrm{dpa}$ ), blastema cell proliferation (14 dpa), chondrogenesis ( $30 \mathrm{dpa}$ ), up to digit formation (42 dpa) [22,24,28]. Histological analysis revealed that epidermal cells had covered the surface of the amputation site at $3 \mathrm{dpa}$ (Figure 3A). qRT-PCR results showed that the expression of Co-c-Fos mRNA was immediately upregulated at $15 \mathrm{~min}$ post-amputation $(p=0.003)$ and then rapidly declined and returned to preamputation levels by $12 \mathrm{~h}$ postamputation (hpa, $p=0.961$ ) (Figure 3B). Also, the protein expression level of Co-c-Fos was detected by Western blot. It was found that the significant upregulation of $\mathrm{Co}-\mathrm{c}$-Fos protein was induced at $1 \mathrm{hpa}(p=0.001)$ and was sustained for $24 \mathrm{~h}$ (Figure 3C). Thus, the expression pattern of the Co-c-Fos gene, both at the mRNA and protein level, suggested its potential role in the early stage of newt limb regeneration. 
A
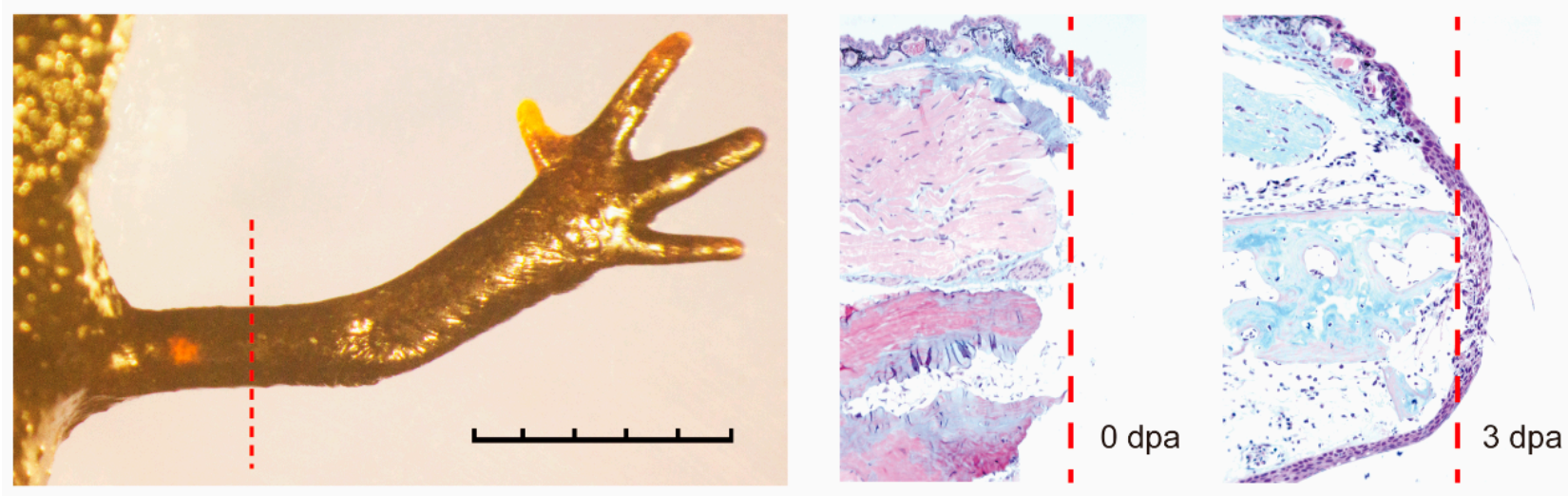

B

C

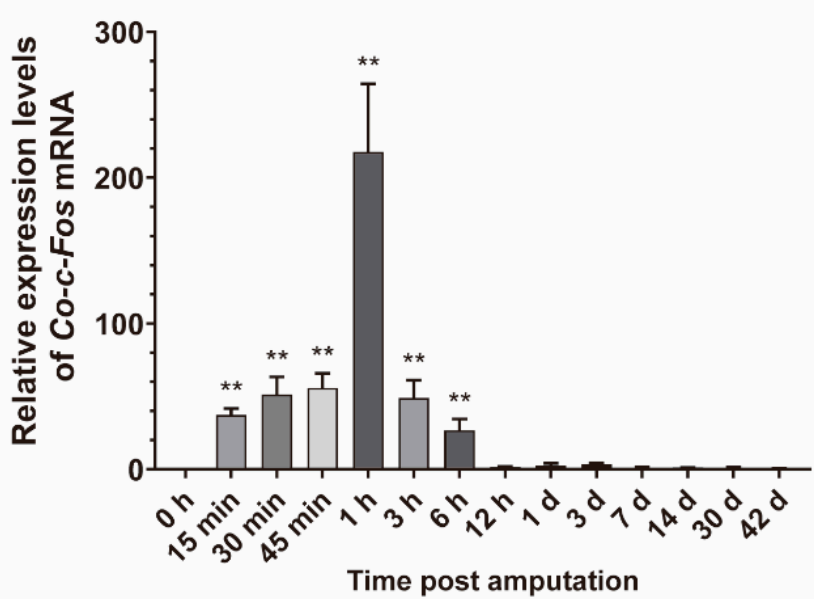

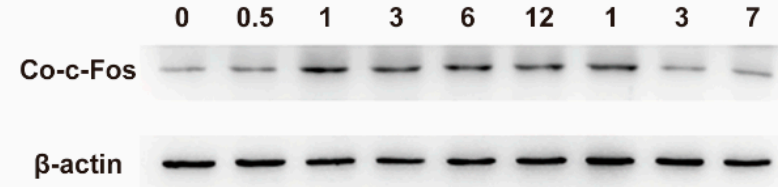

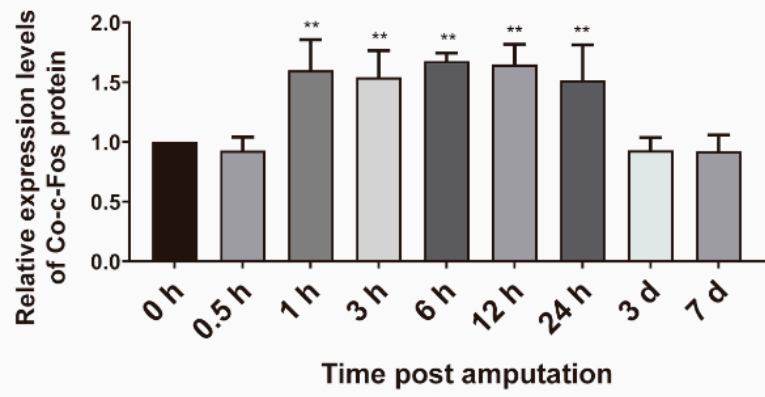

Figure 3. Expression pattern of Co-c-Fos gene during the newt limb regeneration. (A) The histological analysis of the limb regeneration with Masson's trichrome at 0 and 3 days post-amputation. The red dashed line indicated the amputated position of the newt limb. (B) The mRNA expression pattern of Co-c-Fos during C. orientalis limb regeneration. The expression level of Co-c-Fos mRNA at $0 \mathrm{~h}$ was set to one $(n=3)$. (C) Western blot analysis of Co-c-Fos protein at the early stage of $C$. orientalis limb regeneration. The abundance ratio to $\beta$-actin was analyzed by densitometry. Data were analyzed using one-way ANOVA with the least-significant difference test. ${ }^{* *} p<0.05$.

\subsection{Role of Co-c-Fos in the Process of the Newt Wound Healing}

The first step of limb regeneration is the healing of the wound, which is fundamental to the following regenerative processes [2]. To better understand the role of Co-c-Fos in wound healing, a skin wound healing model was established in C. orientalis (Figure 4A), in which the rapid and transient induction of Co-c-Fos was determined (Figure 4B), showing a similar expression pattern as observed in newt limb regeneration. Furthermore, a Fast Green staining method was employed to quickly visualize the wound closure. The Fast Green staining results showed that the wound epidermis had partly covered the wound area at $24 \mathrm{~h}$ and completely covered the wound at $72 \mathrm{~h}$ after wounding. However, the healing process was largely impaired after treatment of T-5224, a selective inhibitor of c-Fos [29] (Figure 4C), indicating the important role of Co-c-Fos in the newt wound healing. 
A

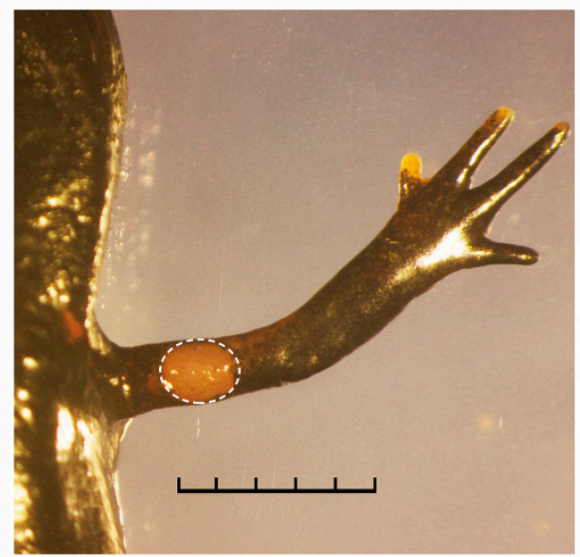

C
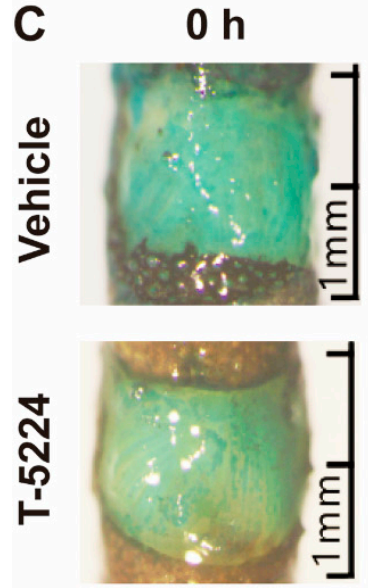

$12 \mathrm{~h}$

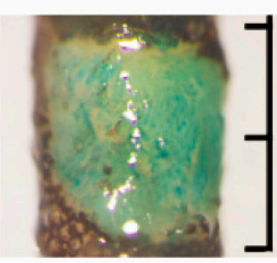

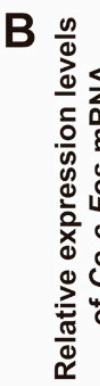

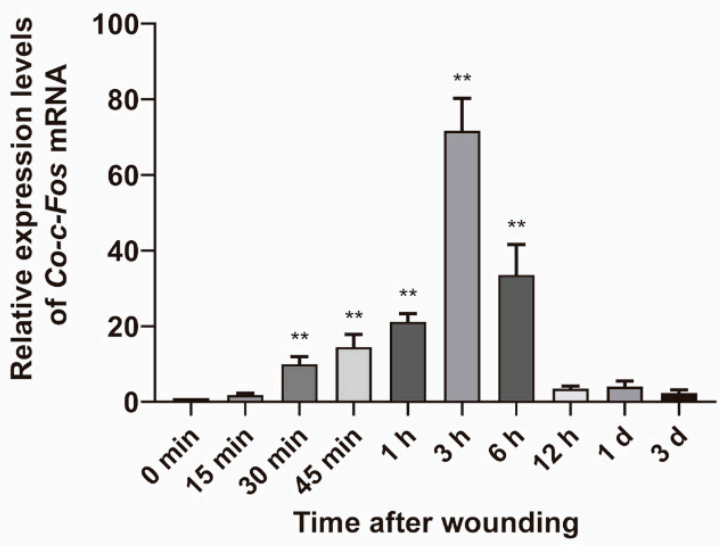

$24 \mathrm{~h}$

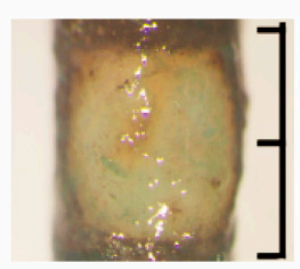

$72 \mathrm{~h}$
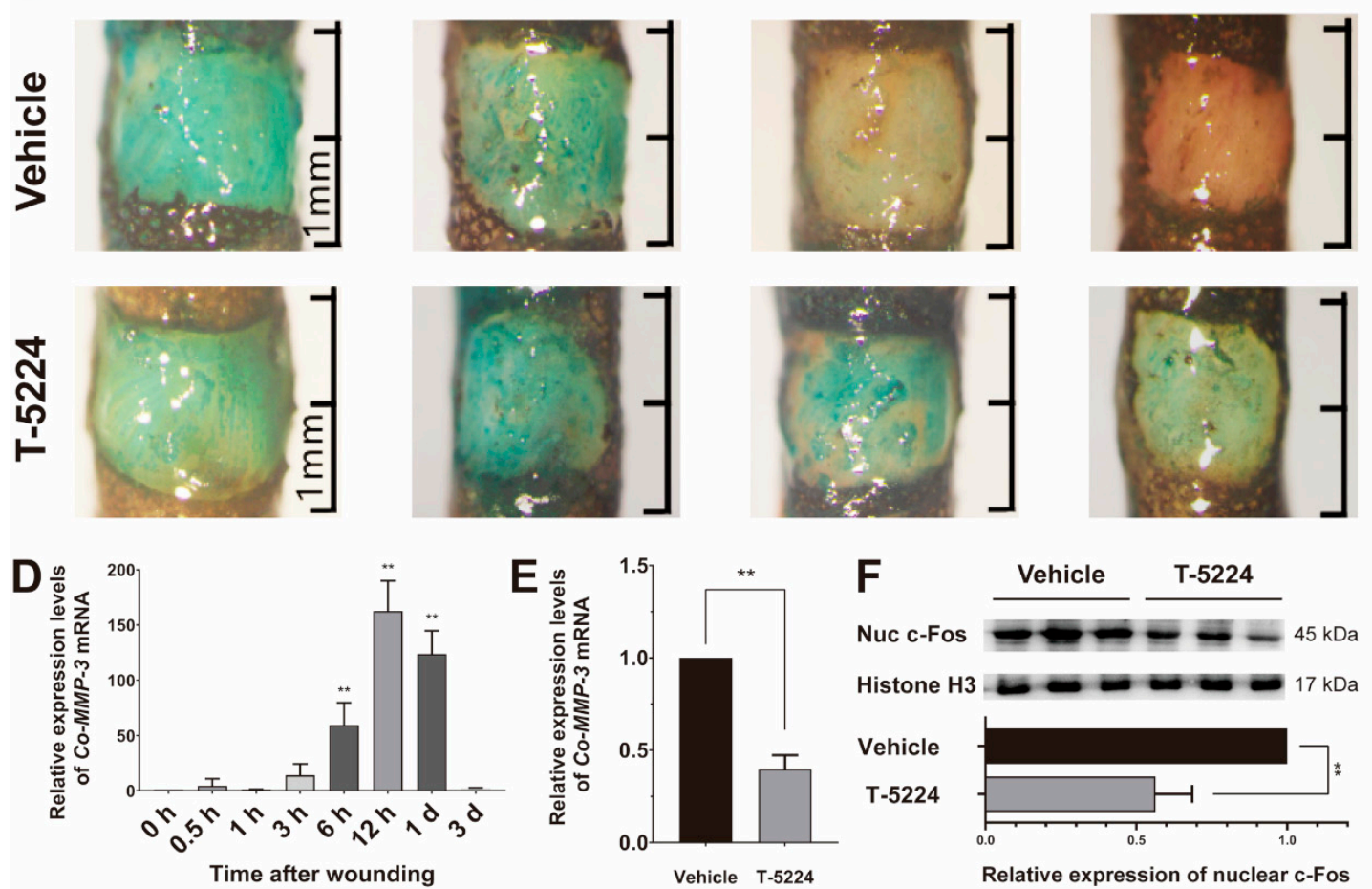

Figure 4. Role of Co-c-Fos in the process of the newt skin wound healing. (A) The newt skin wound healing model. The white outlines indicated the wound made in the limb of $C$. orientalis. Bar $=5 \mathrm{~mm}$. (B) The mRNA expression pattern of Co-c-Fos mRNA during the newt skin wound healing. The mRNA expression level of Co-c-Fos at 0 min after wounding was set to one $(n=3)$. (C) Inhibitory effect of T-5224 on the newt skin wound healing visualized by Fast Green staining at 0,12 , 24, and $72 \mathrm{~h}$ after wounding. (D) The mRNA expression pattern of Co-MMP-3 during the newt skin wound healing. The mRNA expression level of Co-MMP-3 at 0 min after wounding was set to one $(n=3)$. (E) Inhibitory effect of T-5224 on the Co-MMP-3 induction at $12 \mathrm{~h}$ after wounding. (F) Inhibitory effect of T-5224 on the nuclear accumulation of Co-c-Fos protein. The abundance ratio to Histone H3 was analyzed by densitometry. Data were analyzed using one-way ANOVA with the least-significant difference test in (B,D) and Student $t$-test in $(\mathbf{E}, \mathbf{F}) .{ }^{* *} p<0.05$.

Previous studies have revealed that MMP-3, one potential target gene of $c$-Fos [30,31], plays a crucial part in wound epithelium formation during newt limb regeneration [6]. To clarify the underlying mechanism of Co-c-Fos on wound healing, we first examined the expression patterns of $C o-M M P-3$ in the newt skin wound healing model. The expression of Co-MMP-3 mRNA was significantly upregulated within hours of wounding, reaching a peak at $12 \mathrm{~h}$ after wounding $(p<0.001$, Figure $4 \mathrm{D})$. However, the maximum expression of Co-MMP-3 was remarkably suppressed by T-5224 treatment at $300 \mathrm{mM}(p<0.001$, Figure 4E), which effectively suppressed the nuclear accumulation of Co-c-Fos protein as 
manifested by Western blot analysis ( $p=0.003$, Figure $4 \mathrm{~F})$. Additionally, the inhibitory effect of T-5224 on Co-MMP-3 expression was also determined in the newt limb regeneration model (Figure S2). Together these results suggested that the $c$-Fos mediated wound healing in C. orientalis might be dependent on Co-MMP-3.

\section{Discussion}

In the present study, we first cloned and characterized the Co-c-Fos cDNA. The deduced Co-c-Fos contained a typical bZIP domain present in other known c-Fos proteins. A conserved heptad leucine repeat within the bZIP domain resembles the leucine dimerization motif, which is essential for the dimerization with the Jun subunit to assemble the transcription factor AP-1 [32], thereby stimulating gene transcription of its target genes $[29,33]$. NLS is a highly conserved lysine- and arginine-rich peptide that is essential for proper nuclear localization of transcription factors [34]. However, the mutation of NLS (V141I) appears to take place in reptiles and fixes during evolution. Nevertheless, the V141I mutation does not seem to influence the nuclear targeting of $c$-Fos proteins; at least in our study, the nuclear accumulation of Co-c-Fos was detected (Figure 4F and Figure S2). Taken together, the highly conserved heptad leucine repeat and NLS could be necessary for Co-c-Fos to exert its biological functions.

Next, we profiled the tissue distribution and expression pattern of the Co-c-Fos gene. Previous studies have reported that $c$-Fos is expressed in many types of vertebrate tissues [35,36]. Consistently, Co-c-Fos was found widely, but differentially expressed in various tissues of $C$. orientalis. Additionally, Co-c-Fos was uniformly expressed in both the forelimb and upper limb (Figure 2B), making it probably not involved in determining the proximodistal identity of the newt limb, like Prod-1 [37].

In mammals, the $c$-Fos expression is normally short-lived; it peaks at 30 to $60 \mathrm{~min}$ after stimulation and falls to basal expression after $90 \mathrm{~min}$ [38]. In this study, significant upregulation of $\mathrm{Co}-\mathrm{c}$-Fos expression was also detected immediately after amputation. However, the duration of Co-c-Fos upregulation was much longer (up to $6 \mathrm{hpa}$ ). Interestingly, the abundance of Co-c-Fos protein did not begin to decline until $3 \mathrm{dpa}$ (Figure 3C). The long-term induction of $c$-Fos is also reported in other salamander species, including Notophthalmus viridescens (up to $24 \mathrm{~h}$ post serum stimulation) [39], and the Mexican axolotl (1 day post spinal cord ablation) [21]. However, whether the duration of $c$-Fos expression underlies differences in regenerative competence between species should be further investigated in a future study.

Nevertheless, our results demonstrated that the upregulation of the Co-c-Fos gene was temporally overlapped with the wound healing stage of $C$. orientalis limb regeneration. At this stage, the amputation plane is covered with wound epithelium to minimize tissue damage, infection, and inflammatory response [2]. Then, the wound epithelium forms a thicken structure called the apical epithelial cap (AEC, Figure 3A), which secretes various growth factors to aid in limb outgrowth [40]. Given the importance of wound healing in initiating limb regeneration, we further employed a skin wound model to investigate whether Co-c-Fos takes part in the process of wound healing. The novel benzophenone derivative T-5224, designed by 3D pharmacophore modeling based on the crystal structure of the bZIP domain [29], served as a potential drug to selectively inhibit Co-c-Fos activity. It was noted that T-5224 treatment could retard the process of $C$. orientalis wound healing (Figure 4C), as well as the nuclear accumulation of Co-c-Fos protein (Figure $4 \mathrm{~F}$ and Figure S2), indicating that Co-c-Fos contributed at least partially to the skin wound healing.

Surprisingly, T-5224 appeared to exert an inhibitory effect on the induction of $\mathrm{Co}$ $M M P-3$ expression (Figure 4E). Prior studies have noted the importance of MMP-3 in the process of wound healing during salamander limb regeneration [6,7]. In mammalians, MMP-3 expression is closely associated with cell migration [41-43], and notably, mice that lacked $M M P-3$ exhibit impaired skin healing, due to inadequate wound contraction [44]. In accordance with the present results, previous studies have demonstrated that the $M M P-3$ expression can be partially inhibited by a c-Fos inhibitor. Administration of T-5224 prevents 
arthritis in a mouse model by reducing the amount of $M M P-3$ in vivo in sera and joints and in vitro in synovial cell and chondrocyte cultures [29,45]. T-5224 also significantly suppress IL-1 $\beta$-induced $M M P$-3 expression in human nucleus pulposus cells and a mouse explant culture model of intervertebral disc (IVD) degeneration [46]. Therefore, we speculate that Co-c-Fos might participate in wound healing by modulating the expression of its potential target gene $M M P-3$.

Supplementary Materials: The following are available online at https://www.mdpi.com/2073-442 5/12/2/205/s1, Figure S1: Multiple sequence alignment of c-Fos amino acid sequences, Figure S2: Inhibitory effect of T-5224 on the Co-MMP-3 induction in the newt limb regeneration model. Table S1: PCR primers used in this study, Table S2: $c$-Fos amino acid sequence identity comparison with other species.

Author Contributions: The authors contributed in the following ways: Y.Y. conceived and designed the project. G.Y., Y.F., Z.M., D.W. and S.L. planned and executed experiments. F.C. and J.C. analyzed the data. G.Y. and Y.Y. wrote the paper. All authors have read and agreed to the published version of the manuscript.

Funding: This work was supported by the National Nature Science Foundation of China (No. 31900330, 31771055, and 31971286) and the Natural Science Basic Research Plan in Shaanxi Province of China (No.2017JQ3021).

Institutional Review Board Statement: The study was conducted according to the guidelines of the Declaration of Helsinki, and approved by the Ethics Committee of Northwest University. All surgeries were performed under anesthesia with $0.1 \%$ Tricaine methanesulfonate (MS-222, Sigma-Aldrich, USA), and all efforts were made to minimize suffering.

Informed Consent Statement: Not applicable.

Data Availability Statement: All relevant data are within the article. The data that support the findings of this study are available from the corresponding author upon reasonable request.

Conflicts of Interest: The authors declare that there is no conflict of interests.

$\begin{array}{ll}\text { Abbreviations } \\ \text { IEGs } & \text { immediate-early genes } \\ \text { AP-1 } & \text { activator protein 1 } \\ \text { bZIP } & \text { basic leucine zipper } \\ \text { NLS } & \text { Nuclear localization sequence } \\ \text { UTR } & \text { untranslated region } \\ \text { MMP } & \text { matrix metalloproteinase } \\ \text { AEC } & \text { apical epithelial cap } \\ \text { dpa } & \text { days post-amputation } \\ \text { hpa } & \text { hours post-amputation }\end{array}$

\section{References}

1. Brockes, J.P.; Kumar, A. Comparative aspects of animal regeneration. Annu. Rev. Cell Dev. Biol. 2008, 24, 525-549. [CrossRef] [PubMed]

2. Yokoyama, H. Initiation of limb regeneration: The critical steps for regenerative capacity. Dev. Growth Differ. 2008, 50, 13-22. [CrossRef] [PubMed]

3. Kragl, M.; Knapp, D.; Nacu, E.; Khattak, S.; Maden, M.; Epperlein, H.H.; Tanaka, E.M. Cells keep a memory of their tissue origin during axolotl limb regeneration. Nature 2009, 460, 60-65. [CrossRef] [PubMed]

4. Miyazaki, K.; Uchiyama, K.; Imokawa, Y.; Yoshizato, K. Cloning and characterization of cdnas for matrix metalloproteinases of regenerating newt limbs. Proc. Natl. Acad. Sci. USA 1996, 93, 6819-6824. [CrossRef] [PubMed]

5. Yang, E.; Gardiner, D.; Carlson, M.; Nugas, C.; Bryant, S. Expression of $m m p-9$ and related matrix metalloproteinase genes during axolotl limb regeneration. Dev. Dyn. Off. Publ. Am. Assoc. Anat. 1999, 216, 2-9.

6. Vinarsky, V.; Atkinson, D.L.; Stevenson, T.J.; Keating, M.T.; Odelberg, S.J. Normal newt limb regeneration requires matrix metalloproteinase function. Dev. Biol. 2005, 279, 86-98. [CrossRef] [PubMed]

7. Mescher, A. Effects on adult newt limb regeneration of partial and complete skin flaps over the amputation surface. J. Exp. Zool. 1976, 195, 117-128. [CrossRef] [PubMed] 
8. Niessen, N.; Balthazart, J.; Ball, G.F.; Charlier, T. C-fos down-regulation inhibits testosterone-dependent male sexual behavior and the associated learning. Eur. J. Neurosci. 2013, 38, 3325-3337. [CrossRef]

9. Clark, C.E.; Hasan, M.; Bousso, P. A role for the immediate early gene product c-fos in imprinting t cells with short-term memory for signal summation. PLoS ONE 2011, 6, e18916. [CrossRef]

10. Van Straaten, F.; Muller, R.; Curran, T.; Van Beveren, C.; Verma, I.M. Complete nucleotide sequence of a human c-onc gene: Deduced amino acid sequence of the human c-fos protein. Proc. Natl. Acad. Sci. USA 1983, 80, 3183-3187. [CrossRef]

11. Curran, T.; Gordon, M.B.; Rubino, K.L.; Sambucetti, L.C. Isolation and characterization of the $c-f o s$ (rat) cdna and analysis of post-translational modification in vitro. Oncogene 1987, 2, 79-84. [PubMed]

12. Fujiwara, K.T.; Ashida, K.; Nishina, H.; Iba, H.; Miyajima, N.; Nishizawa, M.; Kawai, S. The chicken $c$-fos gene: Cloning and nucleotide sequence analysis. J. Virol. 1987, 61, 4012-4018. [CrossRef] [PubMed]

13. Li, Y.; Kim, I.; Kim, Y.J.; Kim, M.K.; Yoon, Y.; Lee, Y.; Lee, J. Cloning and sequence analysis of the self-fertilizing fish Rivulus marmoratus immediate early gene $c$-fos. Mar. Environ. Res. 2004, 58, 681-685. [CrossRef] [PubMed]

14. Wang, S.H.; Xu, X.; Xu, F.; Meng, Y.; Sun, C.; Shi, L.; Zhao, E. Combined expression of c-jun, c-fos, and p53 improves estimation of prognosis in oral squamous cell carcinoma. Cancer Investig. 2016, 34, 393-400. [CrossRef] [PubMed]

15. Guo, L.; Sans, M.D.; Hou, Y.; Ernst, S.A.; Williams, J.A. C-jun/ap-1 is required for cck-induced pancreatic acinar cell dedifferentiation and DNA synthesis in vitro. Am. J. Physiol. -Gastrointest. Liver Physiol. 2012, 302, G1381-G1396. [CrossRef]

16. Florin, L.; Hummerich, L.; Dittrich, B.T.; Kokocinski, F.; Wrobel, G.; Gack, S.; Schorppkistner, M.; Werner, S.; Hahn, M.; Lichter, P. Identification of novel ap-1 target genes in fibroblasts regulated during cutaneous wound healing. Oncogene 2004, 23, 7005-7017. [CrossRef]

17. Cheng, B.; Liu, H.; Fu, X.; Sun, T.; Sheng, Z. Recombinant human platelet-derived growth factor enhanced dermal wound healing by a pathway involving erk and c-fos in diabetic rats. J. Dermatol. Sci. 2007, 45, 193-201. [CrossRef]

18. Stern, S.; Knoll, B. Cns axon regeneration inhibitors stimulate an immediate early gene response via map kinase-srf signaling. Mol. Brain 2014, 7, 86. [CrossRef]

19. Ott, C.E.; Bauer, S.; Manke, T.; Ahrens, S.; Rodelsperger, C.; Grunhagen, J.; Kornak, U.; Duda, G.N.; Mundlos, S.; Robinson, P.N. Mechanical strain of osteoblasts induces promiscuous and depolarization-induced immediate-early response genes. Bone 2009, 44, S298. [CrossRef]

20. Hui, T.; Mizuguchi, T.; Sugiyama, N.; Avital, I.; Rozga, J.; Demetriou, A.A. Immediate early genes and p21 regulation in liver of rats with acute hepatic failure. Am. J. Surg. 2002, 183, 457-463. [CrossRef]

21. Sabin, K.; Santosferreira, T.; Essig, J.; Rudasill, S.E.; Echeverri, K. Dynamic membrane depolarization is an early regulator of ependymoglial cell response to spinal cord injury in axolotl. Dev. Biol. 2015, 408, 14-25. [CrossRef] [PubMed]

22. Tang, J.; Yu, Y.; Zheng, H.; Yin, L.; Sun, M.; Wang, W.; Cui, J.; Liu, W.; Xie, X.; Chen, F. Itraq-based quantitative proteomic analysis of Cynops orientalis limb regeneration. BMC Genom. 2017, 18, 750. [CrossRef] [PubMed]

23. Yu, Y.; Tang, J.; Su, J.; Cui, J.; Xie, X.; Chen, F. Integrative analysis of micrornaome, transcriptome, and proteome during the limb regeneration of Cynops orientalis. J. Proteome Res. 2019, 18, 1088-1098. [CrossRef] [PubMed]

24. Cui, J.; Zheng, H.; Zhang, J.; Jia, L.; Feng, Y.; Wang, W.; Li, H.; Chen, F. Profiling of glycan alterations in regrowing limb tissues of Cynops orientalis. Wound Repair Regen. 2017, 25, 836. [CrossRef] [PubMed]

25. Weisenthal, L.M.; Marsden, J.A.; Dill, P.L.; Macaluso, C.K. A novel dye exclusion method for testing in vitro chemosensitivity of human tumors. Cancer Res. 1983, 43, 749-757.

26. Bornberg-Bauer, E.; Rivals, E.; Vingron, M. Computational approaches to identify leucine zippers. Nucleic Acids Res. 1998, 26, 2740-2746. [CrossRef]

27. Corpet, F. Multiple sequence alignment with hierarchical clustering. Nucleic Acids Res. 1988, 16, 10881-10890. [CrossRef]

28. Feng, Y.; Feng, J.; Zheng, H.; Wang, W.; Chen, F.; Yu, Y.; Cui, J. Molecular cloning, characterization, and expression analysis of the three cysteine and glycine-rich protein genes in the chinese fire-bellied newt Cynops orientalis. Gene 2018, 647, 226-234. [CrossRef]

29. Aikawa, Y.; Morimoto, K.; Yamamoto, T.; Chaki, H.; Hashiramoto, A.; Narita, H.; Hirono, S.; Shiozawa, S. Treatment of arthritis with a selective inhibitor of c-fos/activator protein-1. Nat. Biotechnol. 2008, 26, 817-823. [CrossRef]

30. Reunanen, N.; Li, S.; Ahonen, M.; Foschi, M.; Han, J.; Kähäri, V. Activation of p38 $\alpha$ mapk enhances collagenase-1 (matrix metalloproteinase (mmp)-1) and stromelysin-1 (mmp-3) expression by mrna stabilization. J. Biol. Chem. 2002, 277, 32360-32368. [CrossRef]

31. Kim, J.; Kim, S.; Noh, E.; Song, H.; Lee, G.; Kwon, K.; Lee, Y. Reversine inhibits mmp-1 and mmp-3 expressions by suppressing of ros/mapk/ap-1 activation in uv-stimulated human keratinocytes and dermal fibroblasts. Exp Derm. 2018, 27, 298-301. [CrossRef] [PubMed]

32. Glover, J.N.; Harrison, S.C. Crystal structure of the heterodimeric bzip transcription factor c-fos-c-jun bound to DNA. Nature 1995, 373, 257-261. [CrossRef] [PubMed]

33. Karin, M.; Liu, Z.; Zandi, E. Ap-1 function and regulation. Curr. Opin. Cell Biol. 1997, 9, 240-246. [CrossRef]

34. Dingwall, C.; Laskey, R. Nuclear targeting sequences-a consensus? Trends Biochem. Sci. 1991, 16, 478-481. [CrossRef]

35. Li, H.; Xie, P.; Li, G.; Hao, L.; Xiong, Q. In vivo study on the effects of microcystin extracts on the expression profiles of protooncogenes (c-fos, c-jun and c-myc) in liver, kidney and testis of male wistar rats injected i.V. With toxins. Toxicon 2009, 53, 169-175. [CrossRef] 
36. Chatani, K.; Kawakami, M.; Weinstein, J.N.; Meller, S.T.; Gebhart, G.F. Characterization of thermal hyperalgesia, c-fos expression, and alterations in neuropeptides after mechanical irritation of the dorsal root ganglion. Spine 1995, 20, 277-289. [CrossRef] [PubMed]

37. Kumar, A.; Gates, P.B.; Brockes, J.P. Positional identity of adult stem cells in salamander limb regeneration. Comptes Rendus Biol. 2007, 330, 485-490. [CrossRef]

38. Greenberg, M.E.; Ziff, E.B. Stimulation of 3t3 cells induces transcription of the $c$-fos proto-oncogene. Nature 1984, 311, 433-438. [CrossRef]

39. Yun, M.H.; Gates, P.B.; Brockes, J.P. Sustained erk activation underlies reprogramming in regeneration-competent salamander cells and distinguishes them from their mammalian counterparts. Stem Cell Rep. 2014, 3, 15-23. [CrossRef]

40. Satoh, A.; Makanae, A.; Hirata, A.; Satou, Y. Blastema induction in aneurogenic state and prrx-1 regulation by mmps and fgfs in ambystoma mexicanum limb regeneration. Dev. Biol. 2011, 355, 263-274. [CrossRef]

41. Huang, S.; Wu, C.; Chao, D.; Wu, C.; Li, C.; Chen, G.; Lan, C. High-glucose-cultivated peripheral blood mononuclear cells impaired keratinocyte function via reduced il-22 expression: Implications on impaired diabetic wound healing. Exp. Derm. 2015, 24, 639-641. [CrossRef] [PubMed]

42. Ko, C.; Wang, W.; Wang, S.; Chu, Y.; Chang, W.; Wang, J. Glycogen synthase kinase-3ß-mediated ccaat/enhancer-binding protein delta phosphorylation in astrocytes promotes migration and activation of microglia/macrophages. Neurobiol. Aging 2014, 35, 24-34. [CrossRef] [PubMed]

43. Wang, S.; Hsu, J.; Ko, C.; Chiu, N.; Kan, W.; Lai, M.; Wang, J. Astrocytic ccaat/enhancer-binding protein delta contributes to glial scar formation and impairs functional recovery after spinal cord injury. Mol. Neurobiol. 2016, 53, 5912-5927. [CrossRef] [PubMed]

44. Bullard, K.; Lund, L.; Mudgett, J.; Mellin, T.; Hunt, T.; Murphy, B.; Ronan, J.; Werb, Z.; Banda, M. Impaired wound contraction in stromelysin-1-deficient mice. Ann. Surg. 1999, 230, 260-265. [CrossRef]

45. Motomura, H.; Seki, S.; Shiozawa, S.; Aikawa, Y.; Nogami, M.; Kimura, T. A selective c-fos/ap-1 inhibitor prevents cartilage destruction and subsequent osteophyte formation. Biochem. Biophys. Res. Commun. 2018, 497, 756-761. [CrossRef]

46. Makino, H.; Seki, S.; Yahara, Y.; Shiozawa, S.; Aikawa, Y.; Motomura, H.; Nogami, M.; Watanabe, K.; Sainoh, T.; Ito, H.; et al. A selective inhibition of c-fos/activator protein-1 as a potential therapeutic target for intervertebral disc degeneration and associated pain. Sci. Rep. 2017, 7, 16983. [CrossRef] 